\title{
Influence of Application of Different Formulations of Phosphate Solubilizing Biofertilizers on Soil Enzymes in Maize Crop
}

\author{
S. Vinod Babu ${ }^{1 *}$, S. Triveni ${ }^{1}$, R. Subhash Reddy ${ }^{1}$ and J. Sathyanarayana ${ }^{2}$ \\ ${ }^{1}$ Department of Agricultural Microbiology and Bioenergy, ${ }^{2}$ Department of Entomology, College \\ of Agriculture, Professor Jayashankar Telangana State Agriculture University, \\ Rajendranagar, Telangana, India \\ *Corresponding author
}

\section{A B S T R A C T}

\begin{tabular}{|l|}
\hline K e y w o r d s \\
$\begin{array}{l}\text { Phosphate } \\
\text { solubilizing } \\
\text { biofertilizers, } \\
\text { Maize. }\end{array}$ \\
\hline Article Info \\
\hline $\begin{array}{l}\text { Accepted: } \\
28 \text { October } 2017 \\
\text { Available Online: } \\
\text { 10 December } 2017\end{array}$ \\
\hline
\end{tabular}

Maize is a cereal crop which is cultivated widely throughout the world and has the highest production among all the cereals. Its importance lies in the fact that it is not only used for human food and animal feed but at the same time it is also widely used for corn starch industry, corn oil production, baby corns and bioethanol production etc. In the present investigation enzymes activity was studied during all the three growth stages. During flowering stage $\mathrm{T}_{7}$ - Carrier + Liquid + Biofilmed PSB biofertilizer being the showed highest dehydrogenase activity $\left(81.53 \mu \mathrm{g}\right.$ TPF $\left.\mathrm{d}^{-1} \mathrm{~g}^{-1}\right)$, acid (123.00 $\mu \mathrm{g}$ p-nitro phenol g $\mathrm{g}^{-1}$ $\left.\mathrm{h}^{-1}\right)$ and alkaline $\left(146.20 \mu \mathrm{g}\right.$-nitro phenol $\left.\mathrm{g}^{-1} \mathrm{~h}^{-1}\right)$ phosphatase activity, urease $(11.40 \mu \mathrm{g}$ of $\mathrm{NH}_{4}{ }^{+}-\mathrm{N} 5 \mathrm{~g}$ soil $^{-1} 2 \mathrm{~h}^{-1}$ ) activity. The major outcome of this study was that Carrier + Liquid + Biofilmed PSB biofertilizer treated Maize (Zea mays) soils of pots showed better enzyme performance in all the(dehydrogenase, phosphatase and urease) activity than other treatments which further resulted in increased plant growth, plant biomass and availability of nutrients

\section{Introduction}

Among different crops, corn (Zea mays) is important in temperate region because of the increasing demand for food and livestock feed. Nitrogen and phosphorus are essential nutrients for plant growth and development in corn (Wua et al., 2005).

The phosphorus is mostly in insoluble form in the soil and not unavailable to plants. Nitrogen fixing and $\mathrm{P}$ solubilizing bacteria are important for plant nutrition by increasing $\mathrm{N}$ and $\mathrm{P}$ uptake by the plants and playing a significant role as a Plant Growth Promoting Rhizobacteria (PGPR). Nitrogen fixation and
P solubilization (Zaidi et al., 2006), production of antibiotics (Zahir et al., 2004) are the principal mechanism for the PGPR.

Soil enzyme activities commonly correlate with microbial parameters (Kandeler and Murer, 1993) and have been shown to be a sensitive index of long-term management effects such as crop rotations, animal and green manures, and tillage. The measurement of soil enzymes can be used as indicative of the biological activity or biochemical process. Soil enzyme activities have potential to provide a unique integrative biological 
assessment of soils because of their relationship to soil biology, easy of measurement and rapid response to changes in soil management (Kirchner et al., 1993).

Urease is an important enzyme in soil which deserves attention. The increased use of urea as fertilizer has led many workers to study its fate in soil and its relationship with soil factors. Cropping history, soil amendments and environmental factors have greater influence on the activity of urease and other enzymes in soils found marked seasonal variations in urease activity. Seasonal variations in the enzymatic activities of soil reported in a number of studies are biologically important because they change the quantity and quality of substrates upon which they act and are responsible for altering the rate of various soil processes influenced by seasonal differences.

\section{Materials and Methods}

\section{Collection of rhizosphere soil}

Rhizosphere soil samples were collected from Maize plots of different treatments at 30, 60 and 90 DAS and used for the estimation of soil enzymes.

\section{Enzyme activity}

Enzymes like Dehydrogenase, Phosphatase and Urease was estimated at different intervals of 30, 60 and 90 DAS.

\section{Dehydrogenase activity}

Dehydrogenase activity was estimated by method as described by Casida et al., (1997). The enzyme activity in $1 \mathrm{~g}$ soil was determined by adding $0.05 \mathrm{~g}$ of $\mathrm{CaCO}_{3}, 2.5 \mathrm{ml}$ of distilled water and $1 \mathrm{ml}$ of $3 \%$ TTC (Try phenyl Tetrazolium Chloride) than stirred with clear glass rod and where it is reduced to light pink TPF (Tri Phenyl Formazon) incubated for $24 \mathrm{~h}$. Later it was dissolved in $10 \mathrm{ml}$ of methanol and finally made up to 25 $\mathrm{ml}$. The intensity of the red colour was measured by using spectrophotometer at 485 $\mathrm{nm}$.

\section{Phosphatase Activity}

Phosphate activity was estimated by following the procedure described by Tabatabai and Bremner (1969) (Acid phosphatases) and Eivazi and Tabatabai (1977) (Alkaline phosphatases).

Phosphatase activity was estimated by taking $1 \mathrm{~g}$ of soil sample and mixed it with $0.2 \mathrm{ml}$ of toluene, $4 \mathrm{ml}$ of MUB (Modified Universal Buffer) and $1 \mathrm{ml}$ of di sodium paranitrophenol solution. This solution was incubated at $37{ }^{\circ} \mathrm{C}$ for $1 \mathrm{~h}$. Then $1 \mathrm{ml}$ of $0.5 \mathrm{M} \mathrm{CaCl}_{2}$ and $4 \mathrm{ml}$ of $0.5 \mathrm{M} \mathrm{NaOH}$ were mixed properly and filtered. The intensity of the yellow colour of filtrate was read on spectrophotometer at 420 nm.

\section{Urease activity}

Urease activity was determined by the method described by Tabatabai and Bremner (1972). To estimate the urease activity $5 \mathrm{~g}$ of soil was taken and $9 \mathrm{ml}$ of distilled water along with 1 $\mathrm{ml}$ of $0.2 \mathrm{M}$ urea solution was added and incubated by swirling in BOD for $2 \mathrm{~h}$. Then $15 \mathrm{ml}$ of $\mathrm{KCl}-\mathrm{AgSO}_{4}$ solution was added and shaken in mechanical shaker.

Later transferred $1 \mathrm{ml}$ of the supernatant solution into a $50 \mathrm{ml}$ volumetric flask and 1 $\mathrm{ml}$ of $6 \%$ EDTA, $2 \mathrm{ml}$ of phenol nitroprusside and $8 \mathrm{ml}$ of buffered hypochlorite was added. After mixing thoroughly, the flasks were kept at $40^{0} \mathrm{C}$ for $30 \mathrm{~min}$ for colour development. Then it was cooled to room temperature and the colour intensity was measured in spectrophotometer at $636 \mathrm{~nm}$. 


\section{Results and Discussion}

Influence of different types of PSB biofertilizers in soil enzyme activity at different intervals $(30,60,90$ DAS $)$

\section{Dehydrogenase activity}

Influence of dehydrogenase activity in response to different inoculations at different intervals of Maize crop growth was studied and presented in Table 1. At 30 DAS the dehydrogenase activity was highest in $\mathrm{T}_{7}-$ Carrier + Liquid + Biofilmed PSB biofertilizer (12.50 $\mu \mathrm{g}$ TPF d $\left.\mathrm{d}^{-1} \mathrm{~g}^{-1}\right)$ and in $\mathrm{T}_{1}$ Carrier based PSB biofertilizer (3.26 $\mu \mathrm{g}$ TPF $\left.\mathrm{d}^{-1} \mathrm{~g}^{-1}\right)$.

At 60 DAS dehydrogenase activity was found highest in $\mathrm{T}_{7}-$ Carrier + Liquid + Biofilmed PSB biofertilizer $\left(81.53 \mu \mathrm{g}\right.$ TPF $\left.\mathrm{d}^{-1} \mathrm{~g}^{-1}\right)$ and lowest activity in case of $\mathrm{T}_{4}-$ Carrier based PSB biofertilizer + Liquid PSB biofertilizer (40.96 $\mu \mathrm{g}$ TPF $\mathrm{d}^{-1} \mathrm{~g}^{-1}$ ). At $90 \quad$ DAS dehydrogenase activity was decreased by 50 $\%$ compared to activity at 60 DAS. However highest activity was seen in $\mathrm{T}_{7}-$ Carrier + Liquid + Biofilmed PSB biofertilizer (39.80 $\mu \mathrm{g}$ TPF $\mathrm{d}^{-1} \mathrm{~g}^{-1}$ ) and lowest activity was recorded in the $T_{1}$ - Carrier based PSB biofertilizer $\left(42.16 \mu \mathrm{g}\right.$ TPF d $\left.\mathrm{d}^{-1} \mathrm{~g}^{-1}\right)$.

The results revealed that higher enzyme activity at flowering stage and least at harvest stage, this might be due to variation in organic carbon levels might acts as energy source for proliferating the microbial population. Thus it is inferred that higher rates of $\mathrm{N}, \mathrm{P}$ and $\mathrm{K}$ fertilization with organic carbon enhanced the activities of soil dehydrogenase activity.

Nannipieri et al., (2003) reported that dehydrogenase activity reflects the oxidative activity or intensity of the metabolism of soil micro flora and can be used as an indicator of microbial activity.

\section{Urease activity}

The urease activity analyzed in the soil samples at different growth stages are shown in Table 1. At 30 DAS highest activity was recorded in $\mathrm{T}_{7}$ - Carrier + Liquid + Biofilmed PSB biofertilizer $\left(6.40 \mu \mathrm{g}\right.$ of $\mathrm{NH}_{4}^{+}-\mathrm{N} 5 \mathrm{~g}$ soil $\left.^{-1} 2 \mathrm{~h}^{-1}\right)$ and lowest activity was recorded in $\mathrm{T}_{1}$ - Carrier based PSB biofertilizer(3.60 $\mu \mathrm{g}$ of $\mathrm{NH}_{4}{ }^{+}-\mathrm{N} 5 \mathrm{~g} \mathrm{soil}^{-1} 2 \mathrm{~h}^{-1}$ ).

At 60 DAS maximum urease activity was observed in $\mathrm{T}_{7}$ - Carrier + Liquid + Biofilmed PSB biofertilizer $\left(11.40 \mu \mathrm{g}\right.$ of $\mathrm{NH}_{4}{ }^{+}-\mathrm{N} 5 \mathrm{~g}$ soil $^{-1} 2 \mathrm{~h}^{-1}$ ) and least was recorded in $\mathrm{T}_{2}$ Liquid PSB biofertilizer (4.20 $\mu \mathrm{g}$ of $\mathrm{NH}_{4}{ }^{+}-\mathrm{N}$ $\left.5 \mathrm{~g} \mathrm{soil}^{-1} 2 \mathrm{~h}^{-1}\right)$.

At 90 DAS maximum urease activity was found in $\mathrm{T}_{7}-$ Carrier + Liquid + Biofilmed PSB biofertilizer $\left(7.63 \mu \mathrm{g}\right.$ of $\mathrm{NH}_{4}{ }^{+}-\mathrm{N} 5 \mathrm{~g}$ soil $^{-1} 2 \mathrm{~h}^{-1}$ ) and least was recorded in $\mathrm{T}_{1^{-}}$ Carrier based PSB biofertilizer $(2.40 \mu \mathrm{g}$ of $\mathrm{NH}_{4}^{+}$- N $5 \mathrm{~g}$ soil $^{-1} 2 \mathrm{~h}^{-1}$ ). During flowering stage there was a significant increase in the urease activity and it got decreased towards the harvesting stage.

Urease enzyme activity is often measured as an indicator of the health of microbial communities in the absence of plants. In the present study urease activity was high in $T_{7}$ due to the ammonium strongly interfered both with the urea uptake by Pseudomonas spp and its activity.

Similar results were found by Blonska (2010) who conducted an experiment to determine the activity of dehydrogenases and urease in forest peat soils of different fertility levels.

The results obtained on urease activity were high in wet soils, and the lowest in upland dry soils. The activity of urease was negatively correlated with of carbon content, $\mathrm{C} / \mathrm{N}$ ratio, hydrolytic acidity and moisture. 
Table.1 Effect of different types of phosphate solubilizing biofertilizers on dehydrogenase and urease activity in soil

\begin{tabular}{|c|c|c|c|c|c|c|}
\hline \multirow[b]{2}{*}{ Treatments } & \multicolumn{3}{|c|}{ Dehydrogenase activity ( $\mu$ g TPF d $d^{-1} g^{-1}$ of soil) } & \multicolumn{3}{|c|}{ Urease activity $\left(\mu \mathrm{g}\right.$ of $\left.\mathrm{NH}_{4}{ }^{+}-\mathrm{N} 5 \mathrm{~g} \mathrm{soil}^{-1} 2 \mathrm{~h}^{-1}\right)$} \\
\hline & 30 DAS & 60 DAS & 90 DAS & 30 DAS & 60 DAS & 90 DAS \\
\hline Control & 4.10 & 50.46 & 32.40 & 4.10 & 50.46 & 32.40 \\
\hline $\mathrm{T}_{1}$ & 3.26 & 42.16 & 24.10 & 3.26 & 42.16 & 24.10 \\
\hline $\mathrm{T}_{2}$ & 3.50 & 44.80 & 26.80 & 3.50 & 44.80 & 26.80 \\
\hline $\mathrm{T}_{3}$ & 8.40 & 45.50 & 29.70 & 8.40 & 45.50 & 29.70 \\
\hline $\mathrm{T}_{4}$ & 6.20 & 40.96 & 26.40 & 6.20 & 40.96 & 26.40 \\
\hline $\mathrm{T}_{5}$ & 9.50 & 58.83 & 30.40 & 9.50 & 58.83 & 30.40 \\
\hline $\mathrm{T}_{6}$ & 10.20 & 71.00 & 32.20 & 10.20 & 71.00 & 32.20 \\
\hline $\mathrm{T}_{7}$ & 12.50 & 81.53 & 39.80 & 12.50 & 81.53 & 39.80 \\
\hline CD & 0.189 & 2.072 & 1.029 & 0.189 & 2.072 & 1.029 \\
\hline $\operatorname{SE}(d)$ & 0.088 & 0.969 & 0.481 & 0.088 & 0.969 & 0.481 \\
\hline SE(m) & 0.062 & 0.685 & 0.340 & 0.062 & 0.685 & 0.340 \\
\hline $\mathrm{CV}$ & 1.498 & 2.181 & 1.950 & 1.498 & 2.181 & 1.950 \\
\hline
\end{tabular}

Treatments: Control: RDF, $\mathrm{T}_{1}$ : Carrier based PSB biofertilizer, $\mathrm{T}_{2}$ : Liquid PSB biofertilizer, $\mathrm{T}_{3}$ : Biofilmed PSB biofertilizer, $\mathrm{T}_{4}$ : Carrier based PSB biofertilizer + Liquid PSB biofertilizer, $\mathrm{T}_{5}$ : Carrier based PSB biofertilizer + Biofilmed PSB biofertilizer, $\mathrm{T}_{6}$ : Liquid PSB biofertilizer + Biofilmed PSB biofertilizer, $\mathrm{T}_{7}$ : Carrier + Liquid + Biofilmed PSB biofertilizer. 
Table.2 Effect of different types of phosphate solubilizing biofertilizers on acid and alkaline phosphatase activity in soil

\begin{tabular}{|c|c|c|c|c|c|c|}
\hline \multirow{2}{*}{ Treatments } & \multicolumn{6}{|c|}{ Phosphatase activity $\left(\boldsymbol{\mu g} \mathbf{~ p}\right.$ - nitro phenol $\mathbf{~}^{-\mathbf{1}} \mathbf{g}^{\mathbf{- 1}}$ of soil) } \\
\cline { 2 - 7 } & \multicolumn{2}{|c|}{ 30 DAS } & \multicolumn{2}{c|}{ 60 DAS } & \multicolumn{2}{c|}{ 90 DAS } \\
\cline { 2 - 7 } & Acid & Alkaline & Acid & Alkaline & Acid & Alkaline \\
\hline Control & 19.30 & 21.50 & 24.10 & 58.40 & 12.70 & 20.45 \\
\hline $\mathrm{T}_{1}$ & 46.10 & 50.20 & 91.83 & 96.90 & 18.50 & 32.16 \\
\hline $\mathrm{T}_{2}$ & 47.86 & 50.70 & 92.90 & 100.90 & 19.40 & 34.80 \\
\hline $\mathrm{T}_{3}$ & 50.83 & 51.76 & 96.76 & 130.20 & 20.20 & 37.23 \\
\hline $\mathrm{T}_{4}$ & 46.20 & 40.40 & 84.63 & 99.50 & 17.60 & 30.20 \\
\hline $\mathrm{T}_{5}$ & 58.40 & 65.70 & 111.56 & 137.96 & 20.50 & 39.20 \\
\hline $\mathrm{T}_{6}$ & 60.00 & 67.43 & 112.80 & 141.40 & 22.30 & 38.90 \\
\hline $\mathrm{T}_{7}$ & 62.00 & 70.20 & 123.00 & 146.20 & 28.40 & 39.90 \\
\hline CD & $\mathbf{1 . 3 7 6}$ & $\mathbf{1 . 8 0 4}$ & $\mathbf{3 . 5 3 9}$ & $\mathbf{2 . 5 7 1}$ & $\mathbf{0 . 8 1 9}$ & $\mathbf{2 . 0 1 1}$ \\
\hline SE(d) & $\mathbf{0 . 6 4 3}$ & $\mathbf{0 . 8 4 4}$ & $\mathbf{1 . 6 5 5}$ & $\mathbf{1 . 2 0 3}$ & $\mathbf{0 . 3 8 3}$ & $\mathbf{0 . 9 4 1}$ \\
\hline SE(m) & $\mathbf{0 . 4 5 5}$ & $\mathbf{0 . 5 9 7}$ & $\mathbf{1 . 1 7 0}$ & $\mathbf{0 . 8 5 0}$ & $\mathbf{0 . 2 7 1}$ & $\mathbf{0 . 6 6 5}$ \\
\hline CV & $\mathbf{1 . 6 1 3}$ & $\mathbf{1 . 9 7 9}$ & $\mathbf{2 . 1 9 9}$ & $\mathbf{1 . 2 9 3}$ & $\mathbf{2 . 3 5 1}$ & $\mathbf{3 . 3 7 8}$ \\
\hline
\end{tabular}

Treatments:

Control: RDF.

$\mathrm{T}_{1}$ : Carrier based PSB biofertilizer.

$\mathrm{T}_{2}$ : Liquid PSB biofertilizer.

$\mathrm{T}_{3}$ : Biofilmed PSB biofertilizer.

$\mathrm{T}_{4}$ : Carrier based PSB biofertilizer + Liquid PSB biofertilizer.

$\mathrm{T}_{5}$ : Carrier based PSB biofertilizer + Biofilmed PSB biofertilizer.

$\mathrm{T}_{6}$ : Liquid PSB biofertilizer + Biofilmed PSB biofertilizer.

$\mathrm{T}_{7}$ : Carrier + Liquid + Biofilmed PSB biofertilizer.

Plate.1 Maize crop at different growth stages

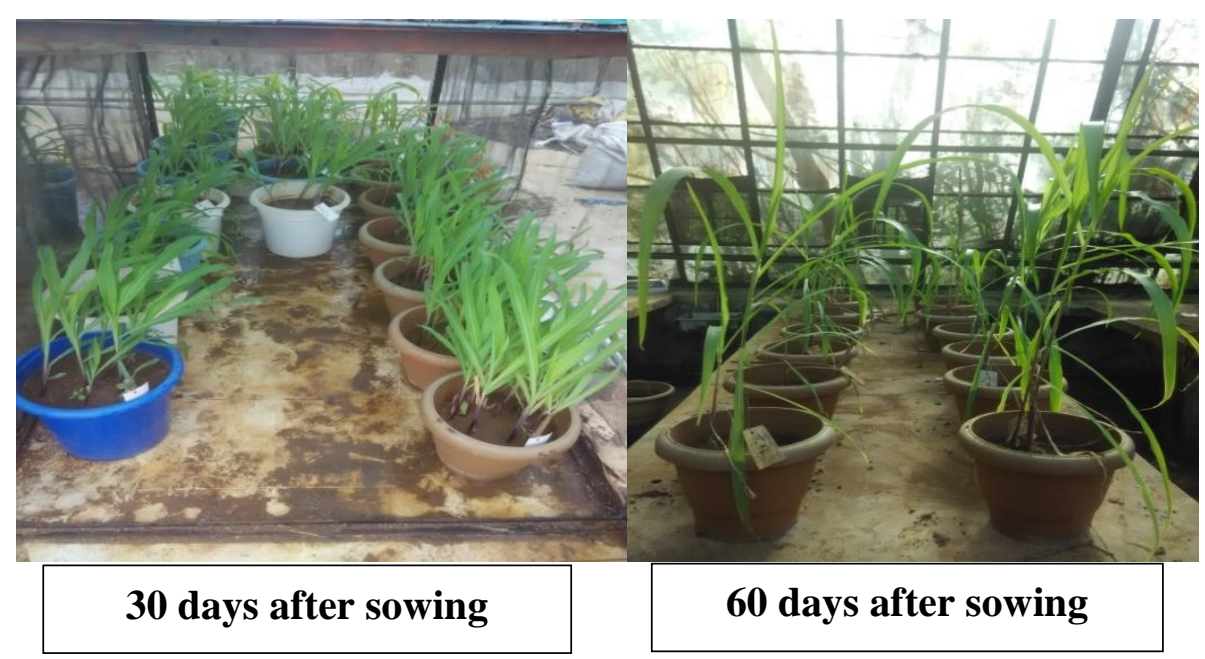




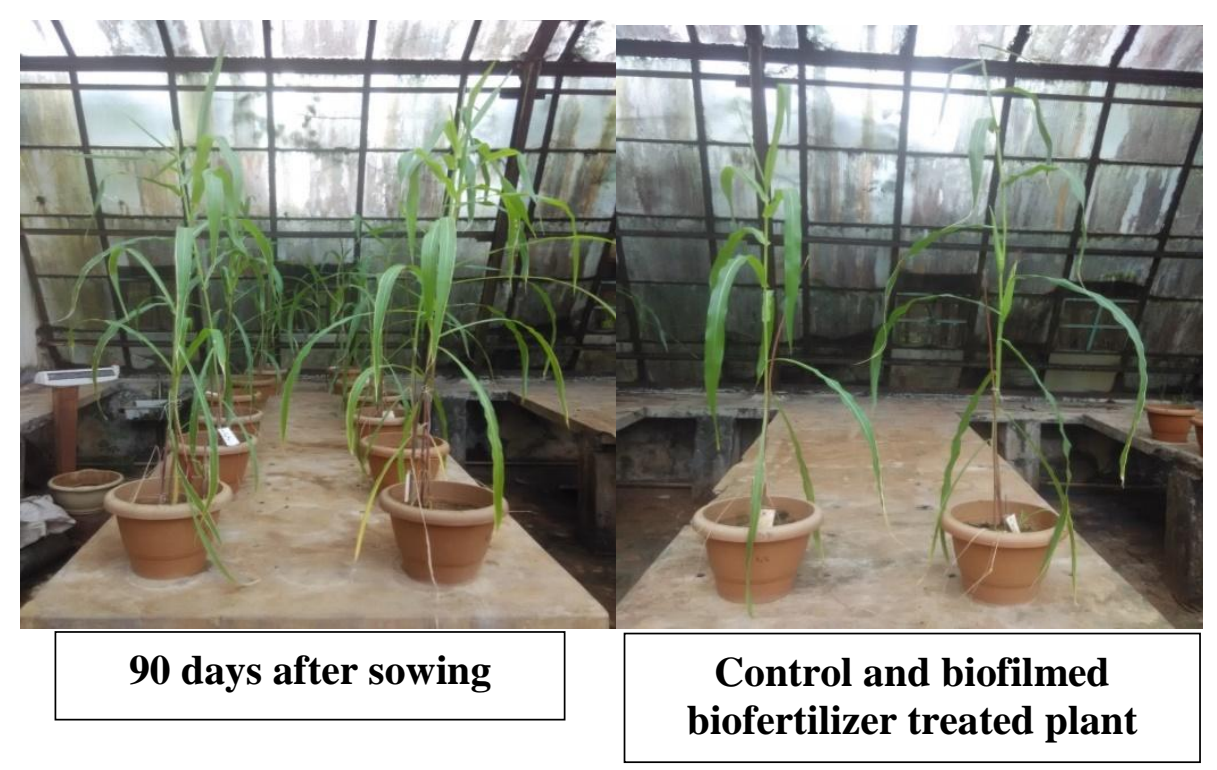

It was observed that the Biofilmed biofertilizers with PSB 6 isolated bacteria and Aspergillus spp showed better results in terms of plant growth attributes compared to other treatments in Maize crop.

\section{Acidic phosphatase activity}

Acidic phosphatase activity was estimated in the soil samples collected from pot culture studied at different intervals of Maize crop is present in Table 2.

At 30 DAS, the maximum acid phosphatase activity was recorded in $\mathrm{T}_{7}$ - Carrier + Liquid + Biofilmed PSB biofertilizer (62.00 $\mu \mathrm{g} \mathrm{p} \mathrm{-}$ nitro phenol $\mathrm{g}^{-1} \mathrm{~h}^{-1}$ ) and least acid phosphatase activity was observed in $\mathrm{T}_{1}$ Carrier based PSB biofertilizer $(46.10 \mu \mathrm{g} \mathrm{p}$ nitro phenol $\mathrm{g}^{-1} \mathrm{~h}^{-1}$ ).

At 60 DAS, the maximum acid phosphatase activity was recorded in $\mathrm{T}_{7}$ - Carrier + Liquid + Biofilmed PSB biofertilizer (123.00 $\mu \mathrm{g} \mathrm{p}$ nitro phenol $\mathrm{g}^{-1} \mathrm{~h}^{-1}$ ) and least acid phosphatase activity was observed in $\mathrm{T}_{4}$ Carrier based PSB biofertilizer + Liquid PSB biofertilizer (84.63 $\mu \mathrm{g} \mathrm{p}$ - nitro phenol $\left.\mathrm{g}^{-1} \mathrm{~h}^{-1}\right)$. Significant decrease in acid phosphatase activity was found in all treatments from flowering to the harvesting stage compared to control (24.10 and $12.70 \mu \mathrm{g} \mathrm{p}$ - nitro phenol $\mathrm{g}^{-1} \mathrm{~h}^{-1}$ ) at 60 and 90 DAS. At 90 DAS the maximum acid phosphatase activity was seen in $\mathrm{T}_{7^{-}}$Carrier + Liquid + Biofilmed PSB biofertilizer $\left(28.40 \mu \mathrm{g} \mathrm{p}\right.$ - nitro phenol $\left.\mathrm{g}^{-1} \mathrm{~h}^{-1}\right)$ and least acid phosphatase activity was recorded in $\mathrm{T}_{4}$ - Carrier based PSB biofertilizer + Liquid PSB biofertilizer (17.60 $\mu \mathrm{g} \mathrm{p}$ - nitro phenol $\mathrm{g}^{-1} \mathrm{~h}^{-1}$ ).

\section{Alkaline phosphatase activity}

Alkaline phosphataseactivity estimated in the soil samples collected from pot culture at different intervals of Maize crop were depicted in Table 2.

At 30 DAS highest alkaline phosphatase activity was observed in $\mathrm{T}_{7}$ - Carrier + Liquid + Biofilmed PSB biofertilizer (70.20 $\mu \mathrm{g} \mathrm{p} \mathrm{-}$ nitro phenol $\mathrm{g}^{-1} \mathrm{~h}^{-1}$ ) and least was recorded in $\mathrm{T}_{1}$ - Carrier based PSB biofertilizer $(46.10 \mu \mathrm{g}$ $\mathrm{p}$ - nitro phenol $\mathrm{g}^{-1} \mathrm{~h}^{-1}$ ). At 60 DAS highest alkaline phosphatase activity was observed in $\mathrm{T}_{7^{-}}$Carrier + Liquid + Biofilmed PSB biofertilizer (146.20 $\mu \mathrm{g} \mathrm{p}$ - nitro phenol $\mathrm{g}^{-1}$ $\mathrm{h}^{-1}$ ) and least was recorded in $\mathrm{T}_{1}-$ Carrier based PSB biofertilizer $(96.90 \mu \mathrm{g} \mathrm{p}$ - nitro phenol $\mathrm{g}^{-1} \mathrm{~h}^{-1}$ ). 
At 90 DAS highest alkaline phosphatase activity was found in $\mathrm{T}_{7}$ - Carrier + Liquid + Biofilmed PSB biofertilizer (39.90 $\mu \mathrm{g} \mathrm{p}$ nitro phenol $\mathrm{g}^{-1} \mathrm{~h}^{-1}$ ) which was on par with $\mathrm{T}_{5}$ - Carrier based PSB biofertilizer + Biofilmed PSB biofertilizer (39.20 $\mu \mathrm{g} \mathrm{p} \mathrm{-} \mathrm{nitro} \mathrm{phenol}$ $\mathrm{g}^{-1} \mathrm{~h}^{-1}$ ) and least was observed in $\mathrm{T}_{4}$ - Carrier based PSB biofertilizer + Liquid PSB biofertilizer (30.20 $\mu \mathrm{g} \mathrm{p}$ - nitro phenol $\left.\mathrm{g}^{-1} \mathrm{~h}^{-1}\right)$.

From above mentioned results the alkaline phosphatase activity was better in $\mathrm{T}_{7}$ - Carrier + Liquid + Biofilmed PSB biofertilizer. Because the enzyme activity is considered as an index of microbial activity. The higher microbial population leads to high activity. The soil enzyme activities were influenced by the nature, age of crop and addition of fertilizers and manures. Results of the present study revealed that the soil enzyme activity was significantly influenced by root colonization due to the acidity in root zone by the activity of microbes present in the form of biofilms.

The results were on par with the results of Adnane et al., (2012) who studied on low soil phosphorus availability increases acid phosphatases activities and affects $P$ partitioning in nodules, seeds and rhizosphere of Phaseolus vulgaris. At lowering, maturity the plants were harvested and analyzed for their phosphatases activities, growth and $\mathrm{P}$ content.

The results showed that dehydrogenase activity was highest in $\mathrm{T}_{7}$ (Carrier + Liquid + Biofilmed PSB biofertilizer), followed by $\mathrm{T}_{6}$ (Liquid PSB biofertilizer + Biofilmed PSB biofertilizer) at flowering stage. Acidic and alkaline phosphatase activity was maximum at 60 DAS in $\mathrm{T}_{7}$ (Carrier + Liquid + Biofilmed PSB biofertilizer). Treatment $\mathrm{T}_{7}$ (Carrier + Liquid + Biofilmed PSB biofertilizer) showed maximum urease activity at 60 DAS. Based on the results obtained in the present study, it can be concluded that the biofilmed biofertilizers were produced more dehydrogenase, phosphatase, urease activity in plants when compared to individual cultures and control. The better ability of these biofilms was due to its higher PGPR activity, strongest interaction between bacteria and fungi and resistant to different environmental conditions which influenced the crop yields.

\section{References}

Adnane, Mustapha, F., Neila, A., Mohamed, F., Bouaziz, S., Jean, J.D., Mohamed, C and Cherki, G. 2012. Low soil phosphorous availability increases acid phosphatases activities and affects $\mathrm{P}$ partitioning in nodules, seeds and rhizosphere of Phaseolus vulgaris. Agriculture. 2: 139-153.

Blonska, E. 2010. Enzyme activity in soils. Folia Forestalia Polonica. 52(1): 20-25.

Casida, L.E. 1997. Microbial metabolic activity in soil as measured by dehydrogenase determinations. Applied and Environmental Microbiology. 6(34): 630-636.

Eivazi, F and Tabatabai, M.A. 1977. Phosphatases in soils. Soil Biology and Biochemistry. 9: 167-172.

Kandeler, E and Murer, E. 1993. Aggregate stability and soil microbial processes in a soil with different cultivation. Geoderma, 56: 503-513.

Kirchner, M.J., Wollum, A.G., King, L.D.1993. Soil microbial populations and activities in reduced chemical input agroecosystems. Soil Sci. Soc. Am. J, 57: 1289- 1295.

Nannipieri, P., Ascher, J., Ceccherini, M.T., Landi, L., Pietramellara, G and Renella, G. 2003. Microbial diversity and soil functions. European Journal of Soil Science. 54: 816-824. 
Tabatabai, M.A and Bremner, J.M. 1972. Assay of urease activity in soils. Soil Biology Biochemistry. 4: 479-487.

Tabatabai, M.A., and Bremner, J.M. 1969. Use of p-nitrophenylphosphate for assay of soil phosphatase activity. Soil Biology Biochemistry. 1:301-307.

Wua, B., Caob, S.C., Lib, Z.H., Cheunga, Z.G and Wonga, K.C. 2005. Effects of biofertilizer containing $\mathrm{N}$-fixer, $\mathrm{P}$ and $\mathrm{K}$ solubilizers and AM fungi on maize growth. Geoderma. 125: 155-162.
Zahir, A., Arshad, Z.M and Frankenberger, W.F. 2004. Plant growth promoting rhizobacteria. Advances in Agronomy.81: 97-168.

Zaidi, A and Mohammad, S. 2006. Coinoculation effects of phosphate solubilizing microorganisms and Glomus fasciculatum on green gram bradyrhizobium symbiosis. Agricultural Seience. 30: 223-230.

\section{How to cite this article:}

Vinod Babu, S., S. Triveni, R. Subhash Reddy and Sathyanarayana, J. 2017. Influence of Application of Different Formulations of Phosphate Solubilizing Biofertilizers on Soil Enzymes in Maize Crop. Int.J.Curr.Microbiol.App.Sci. 6(12): 3771-3778.

doi: https://doi.org/10.20546/ijcmas.2017.612.434 